\title{
MANAGING CROP NUTRIENTS AND LIMESTONE WITH REDUCED FINANCIAL RESOURCES
}

\author{
John E. Sawyer \\ Associate Professor and Extension Soil Fertility Specialist \\ Department of Agronomy \\ Iowa State University
}

Ideally, nutrient and limestone needs are determined by evaluating the potential return expected from each input, with application decisions not being limited by overall financial resources. More realistically, resources are allocated by priority need, and decisions related to fertilizer and limestone use are judged against other crop production needs, enterprise requirements, and overall farm business goals. With the current low commodity prices, and resultant reduced cash flow and potentially inadequate financial resources for some producers to purchase all required production inputs, these decisions become especially important and difficult. In these situations, and when considering at all potential nutrient input needs, the focus should be on garnering the greatest return to the input dollar expended, and targeting areas that will produce the greatest profit. Following is information to help guide fertilization and liming decisions when funds are limited -- keeping in mind that the goal is on ensuring adequate crop production by addressing critical crop input needs, while at the same time attempting to minimize negative impacts from less than optimal production.

\section{Baseline Information}

Decisions regarding fertilization and liming are based on information derived from soil test results. Without this information it is not possible to make informed decisions regarding lime or nutrient applications. In fact, when resources are limited, using soil tests is the best approach to ensure most successful use of input dollars.

If soil testing is a traditional component of crop management, then current soil tests, as well as trends in nutrient and limestone need, will be available to assist in resource allocation decisions. If recent soil tests are not available, or worse yet there are none, then some money should be spent determining this information - it is the only way to understand the potential need for fertilization and liming.

Also, documented records and information on the productivity of soils, fields, or field areas help derive nutrient recommendations that fit reasonable expectations of crop yield.

\section{Liming}

Increasing $\mathrm{pH}$ of acid soils to a range optimal for crop production is the long-term goal of liming programs. Traditionally this means applying limestone if soil $\mathrm{pH}$ falls below 6.0 for straight grass pastures or grass hay, below 6.4 for corn and soybean (below 6.0 on soils with high pH subsoils), and below 6.8 for alfalfa -- with the expectation of raising $\mathrm{pH}$ to 6.5 for straight grass pastures, grass hay, corn, and soybean and to 6.9 for alfalfa production (Voss et al., 1996).

With limited financial resources, some adjustment as to when to begin liming is appropriate. First - high priority application: apply lime to fields or field areas that test less than 5.5, no matter what crop will be grown. Although this may be costly because of the large limestone need, consider liming to raise $\mathrm{pH}$ to 6.5 for row crops and grass forages (6.0 for grass pastures and grass haylands), and to 6.9 for alfalfa (because of economic considerations the amount of lime may need to be reduced, but remember the target $\mathrm{pH}$ will not be reached). Of the crops mentioned here, alfalfa is the most sensitive to low $\mathrm{pH}$, and 
considering the high establishment cost and need for stand longevity, it should have priority for lime application. For crop rotations of corn and soybean, soybean is more sensitive to low $\mathrm{pH}$ than corn and should receive priority liming. Second - desirable application: if soil pH is between 5.5 and 6.0, apply lime, especially for the most sensitive crops like alfalfa and soybean. Third - optional application: if soil $\mathrm{pH}$ is 6.0 to 6.4 then limestone application is recommended, but priority should be to alfalfa, then perhaps before soybean (especially on soils with low pH subsoils), and application before corn not necessary.

The above mentioned application strategy will help with lime allocation on the short term. Next year similar questions will arise as the fields by-passed this year are rotated next year. Limestone applications will correct soil $\mathrm{pH}$ for several years, therefore the above mentioned application strategy inherently provides pH correction for several crops, and therefore costs can be amortized over time.

\section{Nitrogen}

Nitrogen management is critical for profitable corn production. High priority should be focused on determining the amount of $\mathrm{N}$ required, and finding resources to purchase and make needed applications. Also of prime importance for reducing costs is accounting for and utilizing $\mathrm{N}$ from various sources -- for example, due to rotation following alfalfa and soybean, from manure, from various byproducts, and from other fertilizers like starter and ammoniated phosphates. These sources can supply significant amounts of $\mathrm{N}$ to corn, and if properly managed will greatly lower fertilizer $\mathrm{N}$ needs. An example is corn following alfalfa where research by Morris et al. (1993) in Iowa has shown virtually no N fertilization need for firstyear corn after alfalfa (three of 29 sites had positive net return from application of $50 \mathrm{lb}$ N/acre, the rest did not respond to applied $\mathrm{N}$ ). Response to $\mathrm{N}$ is greater and more variable for second-year corn after alfalfa, but still less than for continuous corn (studies by Blackmer et al. (1992) showed 16 of 24 sites did not respond to applied $\mathrm{N}$, but the other 8 had economic optimum rates above $100 \mathrm{lb}$ N/acre).

Crop price and $\mathrm{N}$ cost both influence economic optimal $\mathrm{N}$ rates, with higher rates when $\mathrm{N}$ cost is low and crop price is high, and conversely, lower rates when $\mathrm{N}$ cost is high and crop price is low (examples in Blackmer et al., 1992; Blackmer, 1996). Within a corn price range from $\$ 3.00$ to $\$ 1.50 /$ bu, the reduction in optimum $\mathrm{N}$ rate is not large unless $\mathrm{N}$ costs are high. One item that should be carefully considered in these evaluations is the choice of corn price - the price now may not be what it is in the future or at harvest next fall. Don't necessarily pencil in the lowest price, instead judge where prices may be.

Of particular interest is the response to applied $\mathrm{N}$ that might occur in specific field situations. Use of soil nitrate testing (Late Spring Nitrate Test) can help guide field specific decisions and assist with determination of economic fertilizer $\mathrm{N}$ rates. This test is particularly useful following manure applications where it can add confidence that the planned $\mathrm{N}$ from manure is available to the corn crop.

Risk of $\mathrm{N}$ loss becomes an important issue when refining rates to optimal or perhaps less than optimal if financial resources limit the amount of $\mathrm{N}$ that can be purchased relative to the total need. Spring preplant application close to planting or sidedress typically provides the least risk from loss - although if weather and soil conditions are favorable, late fall application can be comparable, but risk and probability of loss increases because of the increased time the applied $\mathrm{N}$ is exposed to the environment. If fall applications must be made, they should be targeted to soils and geographic areas with lowest loss potential, and application should not occur until soils have cooled sufficiently to slow nitrification (temperature at the 4 inch soil depth $50^{\circ} \mathrm{F}$ and cooling).

\section{Phosphorus and Potassium}

Highest priority for $\mathrm{P}$ and $\mathrm{K}$ applications should be to fields or field areas with soil tests that indicate greatest potential return to the nutrient investment. Long-term $\mathrm{P}$ and $\mathrm{K}$ research in Iowa has shown this 
will be with soil tests in the very low and low categories - soil tests below the optimum range (Mallarino et al., 1991; Webb et al., 1992; Mallarino and Blackmer, 1995). If adequate fertilizer cannot be applied to these soils, then reduced yield and profitability will occur. If manure is available, then application should be targeted to these field areas.

It would be desirable to apply $\mathrm{P}$ and $\mathrm{K}$ to soils testing optimum as yield increase is expected at those soil test levels. However, yield increase and return to the fertilizer cost is not as large as with lower soil tests. For the long-term it may be profitable to maintain soil tests in the optimum range, but in times of tight finances, those applications could be reduced.

On the short term, P and K can be withheld on soils testing slightly above optimum (Voss et al., 1996), however realizing that with crop harvest and resultant removal of nutrients soil tests will decline and increased fertilization will eventually be required. Application at this test level is optional. If a build-up and maintenance approach to $\mathrm{P}$ and $\mathrm{K}$ fertility management is being followed, then once soil tests are built up, fertilizer application can be withheld during tight economic times with no detrimental impact on crop production (which is one goal of that program). Soils testing high and very high have little probability of yield increase from nutrient application, and could have $\mathrm{P}$ and $\mathrm{K}$ withheld for several years before fertilization would be required. Application is not needed. Soils should be tested regularly to monitor changes in soil test levels if fertilization is withheld.

Starter should be applied for corn if soil or environmental conditions frequently result in response to that application. If reduction in recommended $\mathrm{P}$ and $\mathrm{K}$ rates is necessary, then consider two by two starter or banding to enhance efficiency.

Also, credit $\mathrm{P}$ and $\mathrm{K}$ from manure application. Most manure contains significant amounts of crop available $\mathrm{P}$ and $\mathrm{K}$, and in many instances can supply the $\mathrm{P}$ and $\mathrm{K}$ needs of one or more crops.

\section{Secondary and Micronutrients}

Secondary and micronutrient deficiencies can have an impact on productivity if deficient. However, their application should only be considered for confirmed deficiency symptoms or documented yield responses - situations usually tied to special soil and climatic conditions. Blanket or shotgun application, especially when considering maximizing tight financial resources, is not the best approach for applying secondary or micronutrient products. Rather, targeted applications should only be made for specific deficient situations and application requirements. In Iowa most soils supply adequate amounts of these nutrients and likelihood of yield enhancement is relatively low, especially compared to that frequently observed for nitrogen, phosphorus, potassium, and liming.

\section{Summary}

Tight financial resources add to the challenge of profitable crop production. This is especially difficult for management of nutrient and limestone inputs because their cost can be a substantial part of all needed production inputs. With careful attention to the nutrient areas affording greatest potential return, input dollars can be targeted to priority situations critical for successful production. The result may not fit longrange plans or provide optimum results, but can provide acceptable profitability for the short-term. When the financial situation improves, then attention can again be focused on areas that, by necessity, were not addressed during the current time period. 


\section{References}

Blackmer, A.M., T.F. Morris, and B.G. Meese. 1992. Estimating nitrogen fertilizer needs for corn at various management levels. p. 121-134. In Proceedings of the forty-seventh annual corn and sorghum industry research conference. American Seed Trade Assoc., Washington, D.C.

Blackmer, A.M. 1996. How much nitrogen do soybeans leave for corn? p. 49-53. In Proceedings of the eight annual integrated crop management conference. Iowa State University, Ames, IA.

Mallarino, A.P., J.R. Webb, and A.M. Blackmer. 1991. Soil test values and grain yields during 14 years of potassium fertilization of corn and soybean. J. Prod. Agric. 4:562-566.

Mallarino, A.P., and A.M. Blackmer. 1995. Phosphorus and potassium fertilization of corn and soybean. p. 2.30-2.35. In Report of integrated farm management. IFM 16. Iowa State University, Ames, IA.

Morris, T.F., A.M. Blackmer, and N.M. El-Hout. 1993. Optimal rates of nitrogen fertilization for firstyear corn after alfalfa. J. Prod. Agric. 6:344-350.

Voss, R.D., A.P. Mallarino, and R. Killorn. 1996. General guide for crop nutrient recommendations in Iowa. Publication Pm-1688. Iowa State University, Ames, IA.

Webb, J.R., A.P. Mallarino, and A.M. Blackmer. 1992. Effects of residual and annually applied phosphorus on soil test values and yields of corn and soybean. J. Prod. Agric. 5:148-152. 